\title{
Exploring smart grids with simulations in a mobile science exhibition
}

\author{
Huijie Li ${ }^{1 *}$, Ilan Chabay ${ }^{2}$, Ortwin Renn ${ }^{3,4}$, Andreas Weber $^{5}$ and Grace Mbungu ${ }^{4}$
}

\begin{abstract}
Improving the publics' understanding of the energy system is a challenging task. Making citizens aware of how the complex energy system functions and how consumers of energy services can respond to a changing energy environment seems more difficult. In the context of the German energy transition, more active energy consumers are needed, not only in producing electricity on their own but also interacting with suppliers to make the energy system operate in a more efficient way through the development of a "smart grid". This article describes an approach taken with a public education perspective to engage citizens in thinking about the issues we are facing in moving toward a future with greater reliance on renewable energy. We introduced a mobile exhibition, including an interactive simulation game, which offered a perspective on the whole energy system. The goal was to stimulate questions and arouse citizens' interest in learning about the smart grid and help them to prepare for the transition to a smarter way of using energy.
\end{abstract}

Keywords: Energy education, Interactive game, Smart grid, Public exhibition

\section{Review}

\section{Introduction: in the era of "Smart"}

It is a time of an explosion of information technologies. Out of imagination and expectation, our lives are being shaped in a new way. As people on Earth become closer due to the Internet, more opportunities have evolved. Headlines like smart appliances, smart building, smart city, etc. spring up in the news. Everything seems to become smart, interconnected in a network, and can be automatically managed in an optimal way. Just picture yourself remotely starting a heater before you arrive home in cold winter via your smart phone. Life becomes so convenient, as you could set appliances in motion at a specific hour, no matter where you are.

Smart phones are a good example. Hardly anyone can resist the change it brought. Even if you do not use it, you see it being used everywhere. Before the smart phone era, one might not have imagined any other function of a phone other than a phone call. Today, the smart phone provides many functions and options and has reduced the number of devices people carry around.

\footnotetext{
* Correspondence: Huijie.Li@sowi.uni-stuttgart.de

${ }^{1}$ Stuttgart Research Center for Interdisciplinary Risk and Innovation Studies (ZIRIUS), University of Stuttgart, Seidenstr. 36, Stuttgart 70174, Germany Full list of author information is available at the end of the article
}

Owners of smart phones use commuting time to play games, listen to their favorite music, as well as watch videos, all in one device. Moreover, they can easily connect to the Internet, which offers a wide range of services such as Email and social networking apps (Facebook, Twitter, etc.). Surprisingly, the camera of a cell phone with self-photo shooting and good resolution has become an increasingly important function of the smart phone.

Now comes a more complex case: that of the smart electricity grid. It seems far more difficult to imagine than using the smart phone. What is the smart grid exactly?

"A Smart Grid is an electricity network that can cost efficiently integrate the behaviour and actions of all users connected to it - generators, consumers and those that do both - in order to ensure economically efficient, sustainable power system with low losses and high levels of quality and security of supply and safety. Though elements of smartness also exist in many parts of existing grids, the difference between a today's grid and a smart grid of the future is mainly the grid's capability to handle more complexity than today in an efficient and effective way. A smart grid employs innovative products and services together with intelligent monitoring, control, communication, and self-healing technologies" ([1], p. 6).

\section{国 Springer}

(c) $2015 \mathrm{Li}$ et al. Open Access This article is distributed under the terms of the Creative Commons Attribution 4.0 International License (http://creativecommons.org/licenses/by/4.0/), which permits unrestricted use, distribution, and reproduction in any medium, provided you give appropriate credit to the original author(s) and the source, provide a link to the Creative Commons license, and indicate if changes were made. 
In short, in the conventional power grid, we citizens are absolutely passive users and bill payers. Unlike the traditional grid, the future smart grid will allow for two-way exchange of information and power between power suppliers and consumers through the integration of information and communication technologies. This also allows for more efficient coordination among various types and sizes of generation technologies. This means that the suppliers will track electricity usage of consumers in real time and deliver only the quantity of electricity needed at a location at that particular time. Informed consumers will be possible to play an active part in optimizing the operation of the whole electricity system. The smart grid will make consumers more informed of how they are using electricity and encourage them to adjust consumption, especially during highcost, heavy-load times. Consumers are expected, together with suppliers, to make the grid operate in a more transparent, interactive, and efficient way.

In addition, with the rise of roof photovoltaic devices, some citizens have a new role: electricity producer and consumer combined-the so-called prosumer. The smart grid will facilitate the connection and operation of dispersed generation sources better than the old system. Particularly in the context of the energy transition in Germany, which has a goal of increasing renewable energy shares, the smart grid will play a key role in managing the demand in order to match the volatile green energy supply. The opportunity of new roles for consumers brought about by the smart grid and distributed generation raises the questions of whether citizens will be ready and willing to embrace these changes and transform their way of using energy.

To stimulate citizens into thinking of this issue, Baden-Württemberg, a southern state in Germany, arranged for the redesign of its Expedition $\mathrm{N}$ mobile exhibition from a rather traditional experience of simply supplying information to visitors to a more interactive experience designed to stimulate visitors' interest and raise their awareness about the changing energy system. The new design offers a systematic view of the whole energy system through exhibits and information terminals, including an interactive smart grid simulation game delivering vivid experience of the consequences of individual and collective energy consumption. Usually, few people would devote much time to contemplating energy use. This inexpensive mobile exhibition allows laymen to quickly develop an understanding of the complex energy system and intrigues them to become more aware of their energy use patterns in their daily life.

\section{Expedition N-Energy Transition Discovery ${ }^{1}$}

Museums make great contributions to scientific literacy, especially in addressing issues like technologies in rapid change, which therefore complement the function of formal education, enabling people to understand and apply concepts in an increasingly technology-dominated society [2, 3]. Besides, citizens need basic understandings, of energy concepts and processes for example, as a prerequisite for reasoned arguments, to effectively participate in policy-making on these issues [4].

Since September 2010, the Baden-Württemberg Stiftung gGmbH (Baden-Württemberg State Foundation) has operated a mobile exhibition called "Expedition NSustainability for Baden-Württemberg". The Expedition $\mathrm{N}$ science exhibition moves around the state offering information to help citizens better understand issues of sustainable development. One of the main goals of the exhibits is to inspire visitors to make a link between the information they gain and their own lives. It aims at motivating citizens to act in a sustainable way in their daily activities whenever possible. In addition, it could stimulate a dialogue between scientists, the public, and politicians [5]. As the German energy transition is widely and often heatedly discussed as a significant part of future development, the Baden-Württemberg Stiftung refined its goal to give visitors an experience about the energy transition. The modified exhibition named "Energy Transition Discovery" started its tour in October 2013. ${ }^{2}$ The main objective of the newly redesigned Expedition $\mathrm{N}$ is to display the systematic connections between energy supply and demand systems and encourage visitors to be engaged, learn, and develop their personal relationship to the German energy transition. Unlike other traditional exhibitions, this Expedition $\mathrm{N}$ encourages more active participation and interaction. In addition to the introduction of concepts at information terminals and exhibits on energy sources, production, transmission, storage, and environmental impacts, there is a special simulation game platform (see Fig. $1^{3}$ ) to engage visitors in experiencing aspects of how they might interact in new ways in the smart grid electricity system.

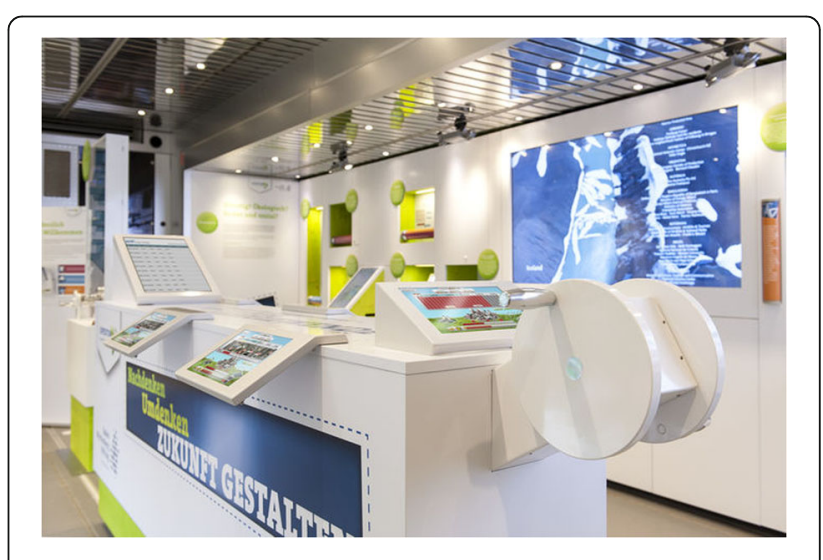

Fig. 1 Smart grid game platform 
Figure $2^{4}$ shows the new appearance of the Expedition $\mathrm{N}^{5}$ The two-story vehicle offers more than $100 \mathrm{~m}^{2}$ of space for a multimedia exhibition, experiments (as one example, see Fig. $3^{6}$ ), film viewing (see Fig. $4^{7}$ ), and other possible forms of events, to facilitate engagement of visitors in multiple ways. For the energy transition theme, there are 20 exhibits (e.g., see Fig. $5^{8}$ ) and multimedia terminals. There are also sections (see Fig. 6) providing information and explanation on energy basics (e.g., basic energy concepts, energy resources), energy supply options and technologies, energy use (e.g., energy-efficient measures), and the role of and impact on sustainability in different aspects of society (e.g., government goals and policies, citizen participation). The linkage between different energy-related topics such as energy physics, energy sources, and energy use and the relationship to energy politics and societal impacts are emphasized. For instance, information terminals provide information not just on energy supply options and forms of consumption but also on the corresponding societal and environmental impacts. Exhibits illustrate facets of the potential economic consequences consistent with sustainable development. Visitors are free to turn to any sections in the exhibition for relevant information at any time.

More interestingly, visitors can freely choose and change roles in the energy system-consumer, supplier, or regulator-enabling them to see divergent views on particular topics and interact virtually with the other roles. In the energy transition, the three roles might face dissimilar aims, challenges, and tasks for energy production, consumption, and storage. Visitors could identify with a specific role and learn corresponding options and impacts on the energy system. In reality, everyone has a role in the energy system, but being aware of other standpoints and responsibilities could put citizens at ease when dealing with the unknown future. For group visits, especially for school students, the tour supports

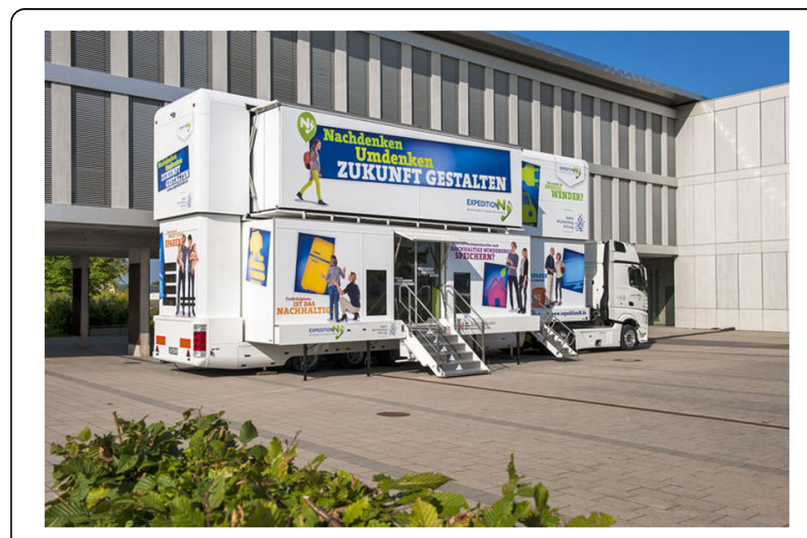

Fig. 2 The new appearance of the Expedition $N$ vehicle after its redesign

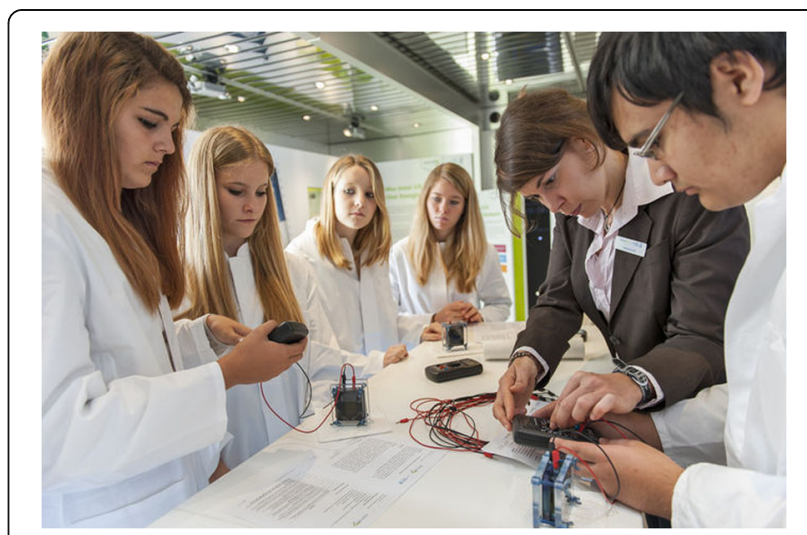

Fig. 3 Dye-sensitized solar cell experiment

not only scientific learning but also engaging youth in the responsibility for action, which will create longlasting impacts. This exciting journey reminds participants of more than just their daily activities of energy use or individual choice of energy-saving or energyefficient measures. Furthermore, in groups, they are able to explore together and discuss the concept of the energy transition and roles of the different stakeholders involved.

\section{Design concept of the smart grid game}

Two of the authors (IC and OR) redesigned the Expedition $\mathrm{N}$ to facilitate the integration of citizens into the new energy regime of Germany. By using the information terminals of the exhibition, citizens use their own interests and learning process to understand the function of the electricity grid, how they would affect the grid as consumers or energy producers, as well as the dynamics of the smart grid in resource allocation. The smart grid concept is not well understood by most people outside the relevant technology industries; therefore,

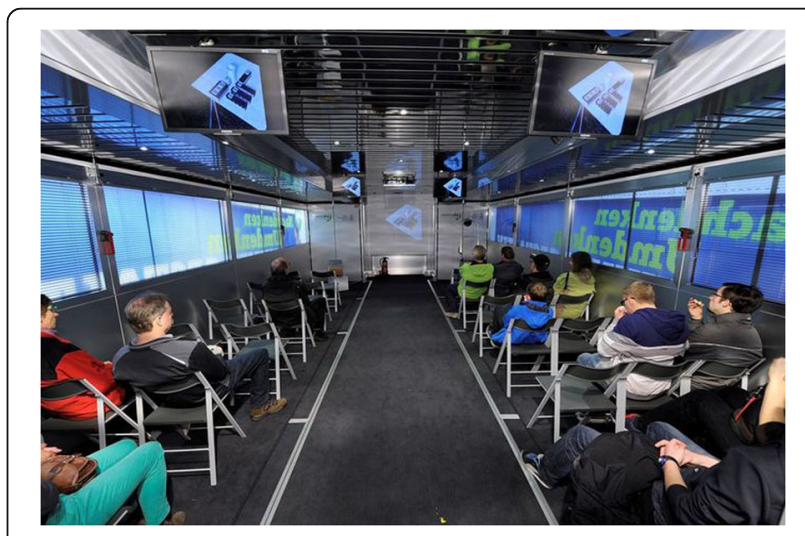

Fig. 4 Film presentation room on the second floor 


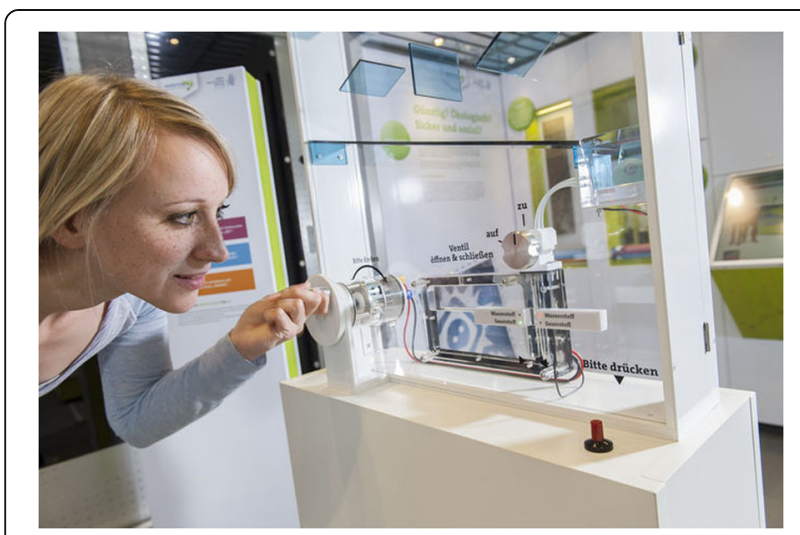

Fig. 5 Oxygen-hydrogen generation and combustion (the "Ping Pong Pinball")

the interactive simulation game aimed to make the idea more accessible and memorable and to stimulate visitors' curiosity and desire to give it a try. The game was designed to increase citizens' awareness and heighten a sense of individual responsibility. Personal responsibility is an important component to engage people in environmental conservation actions, which should be considered well in promoting programs [6]. Generally, museums and science lessons present physical facts about energy technologies, while this mobile exhibition brings out the social aspects of energy issues and the need for collective action. The interactive game can help visitors make better connections between their electricity consumption and personal impact on the energy system, unlike illustrations of home appliance choices, which focus on the efficiency of the device, rather than the actions of the user. Additionally, it allows visitors to experience new roles, such as prosumer with this simulation. By experimenting with different action strategies, visitors may learn as they interact and observe the consequences of their actions on the energy system. In short, the smart grid game supports the envisioned functions by:

- Providing two-way power and information exchanges between suppliers and consumers

- Providing more transparent electricity consumption data

- Demonstrating how consumers could produce and store energy

- Providing visitors with an opportunity to familiarize themselves with matters of demand management

In the smart grid game (see Fig. 1), there are two roles: electricity generators and consumers, which have different user interfaces as showed in Figs. 7 and 8. ${ }^{9}$ Every round of the game allows one generator and up to five consumers around the table, each with a screen with a simulated city on it. Visitors will have a chance to experience what it would look like when $80 \%$ of the electricity comes from renewable energy. The timeline is a virtual week of five weekdays which occupies 4 min.

As long as there is one visitor or a staff member who plays the role of "generator", the game can be played. The generator uses a hand crank to produce electricity needed by all the players in the game. The sum of the electricity demand from all the players imposes the load on the power source, run by the generator with the hand crank. The generator must maintain sufficient power by turning the crank fast enough to satisfy the needs of consumers in the simulated city. Everyone could choose to use electricity at any particular moment, but then the generator may not be able to supply sufficient power to meet the demand at that moment. Consumers make

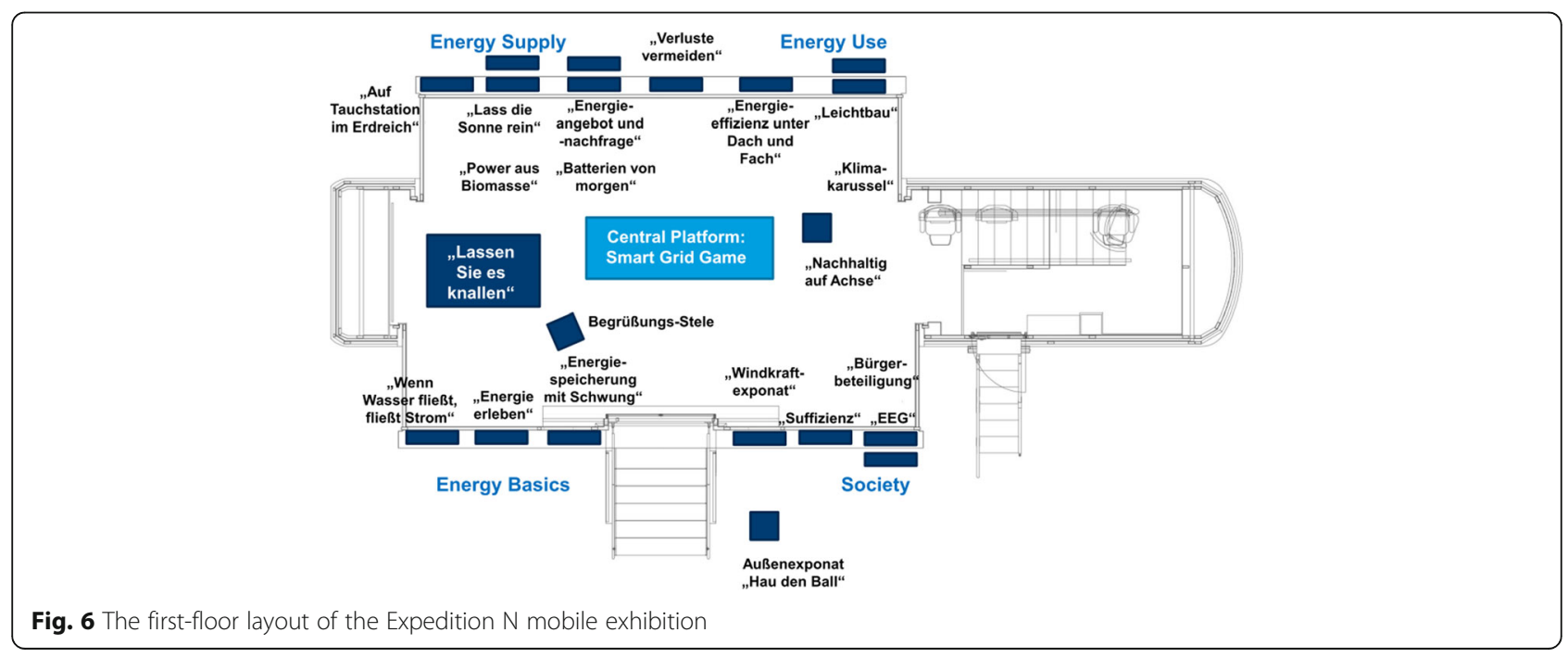




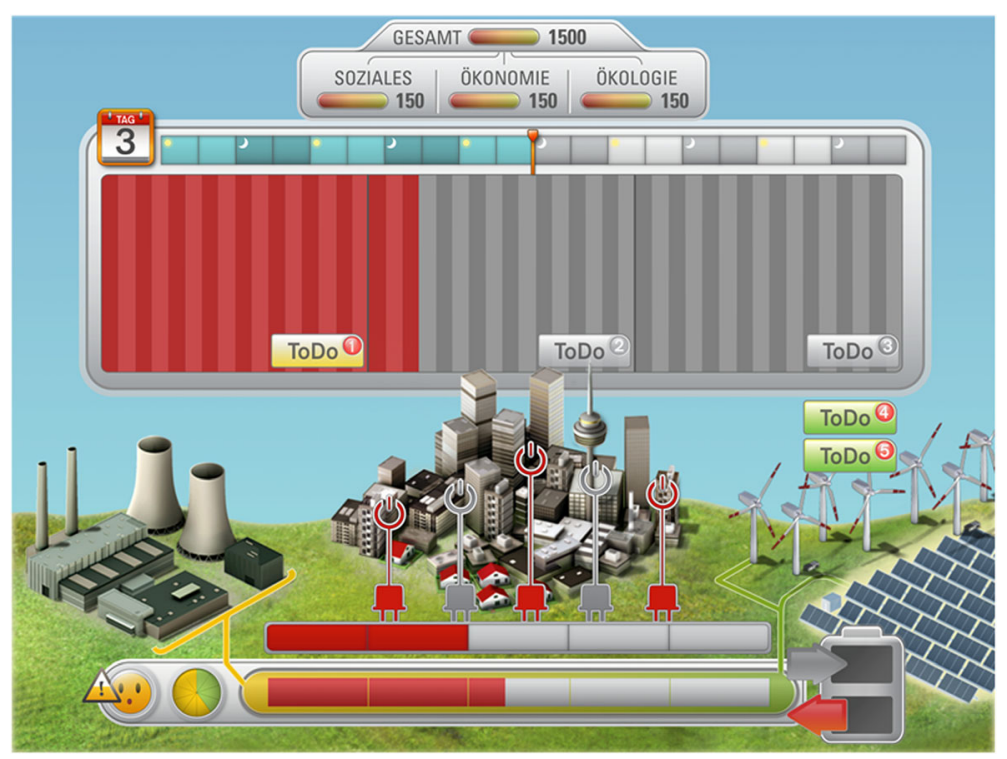

Fig. 7 User interface of electricity generator

individual decisions to use appliances at each moment in their own display. It reminds visitors of their daily consumptions in reality.

For each round of the game, there is only one collective score for the team (the generator and consumers together), which shows its performance in social, economic, and environmental aspects (see Figs. 7 and 8). The group score is an indicator that shows how the virtual society as a whole deals with the balance of electricity supply and demand-the core of the smart grid. The rankings of group scores are displayed on the central screen (see Fig. 1). The generator knows the quantity of electricity produced and consumed (see Fig. 7), and consumers know their consumption conditions after using certain appliances from their own screens (see Fig. 8). Unlike the traditional grid, the smart grid here in the game makes consumers aware of the whole supply and demand system in addition to their own consumption. When the consumption level is high, the generator either provides more electricity, or a blackout happens, which brings that round of the game to an end. To achieve a better score, groups could play a second or third round. An open discussion on possible ways to balance demand and supply in the virtual city is encouraged

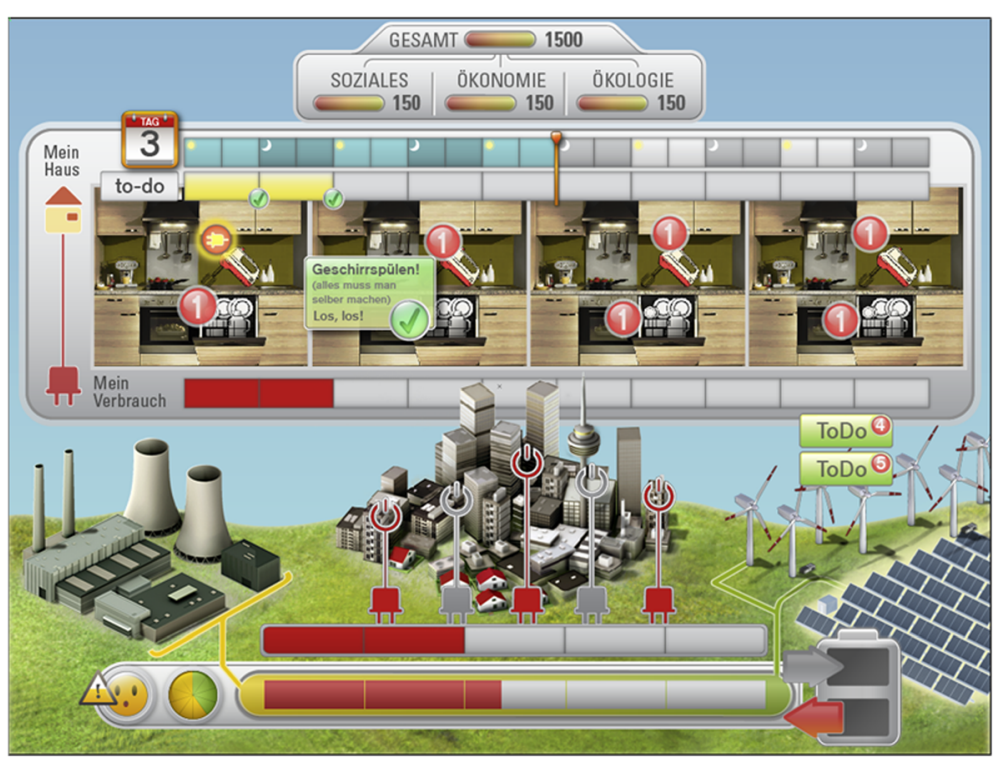

Fig. 8 User interface of electricity consumer 
among group members. Here, the consumers, who add load to the grid at certain times, are expected to take more responsibilities and act: if each cannot cut certain demand, then a collective time plan for shifting energy use would work to match limited supply-that is, "flattening" the peaks in the load by distributing the timing of the load. Only if generators and scattered consumers act as a whole, willing to cooperate with each other, can the electricity system be operated in a more efficient way.

Social interaction plays an important part in visitors' learning experience [7]. In the mobile exhibition, besides staff stimulating visitors' curiosity by initiating discussions, information terminals also pose questions to encourage visitors to find answers. People can engage in active learning in an informal environment provided by the smart grid game and have opportunities to interact in the game and dialogues with other visitors.

\section{Methodological approaches to the design of the exhibition} The design of the exhibition on the energy system was based upon the accumulated experience of informal learning institutions worldwide over the past 40 years (see for example, $[3,8,9]$ ). The authors' approach to the redesign of the Expedition $\mathrm{N}$ experience was to focus on a constructivist approach using inquiry and experiential learning that engages each visitor in an open way, amenable to his or her own learning style, interests, and prior knowledge. The goals are to stimulate curiosity and inquiry, rather than to supply information without regard to the individual. This allows the exhibition to be accessible, relevant, and memorable for visitors with diverse backgrounds, ages, and educational levels.

The main emphasis is on inquiry-based learning, drawing on individual as well as collective experience. Each visitor is free to take a specific role as an energy consumer, provider, or regulator. All written explanations are color coded to reflect the three different roles. Visitors are then encouraged to exchange their experience and compare their assigned roles with the overall energy situation. Furthermore, many exhibits include experimental designs that allow visitors to learn from trial and error. Moreover, several exhibits contain questions for further discussion or personal reflection. Self-testing devices (e.g., How much energy do I conserve?) and exercises complement the experimental setup. Feedback from visitors concluded that a mixture of information, self-testing, experimentation, and discussion opportunities were well suited to raise the interest of the visitors and to keep them attentive to the various topics of the exhibition.

\section{Impact and discussion}

Since the start of the "Expedition N-Sustainability for Baden-Württemberg" in September 2010, there have been more than 470,000 visitors. ${ }^{10}$ Between September 2010 and April 2015, the Expedition N vehicle has visited 319 locations. ${ }^{11}$ Figure $9^{12}$ presents some of the places the mobile exhibition has visited. The Expedition $\mathrm{N}$ vehicle makes school tours, as well as provides event space for energy-related projects, workshops, and meetings.

On October 3, 2013, the new "Expedition N-Energy Transition Discovery" started its tour from Stuttgart, where 500,000 people gathered to celebrate the German National Day. Here, citizens had firsthand experiences of the energy transition. The German energy transition is a heatedly debated topic among politicians and the public alike. The new Expedition $\mathrm{N}$ grasped this rare opportunity to provide information of the complex energy system and support citizens in pursuit of their roles and responsibilities in the energy transition (see Fig. $10^{13}$ ). On a single day, the National Holiday in Germany where the vehicle was centrally located in the center of Stuttgart, more than 5000 visitors were registered who wanted to obtain additional materials for energy conservation ([10], p. 49). One family said this after experiencing the smart grid game: "In future we will use washing machine more often at night to reduce load on the grid" ([10], p. 49).

For the German energy transition, technology is becoming more sophisticated with the smart grid and therefore more informed and engaged consumers are also indispensable. Both smart technology and smart consumers matter to the success of the future energy system. The smart grid, for example, involves packages of technologies, some of which is still not accessible or available to the general public. The information and experience provided by the Expedition $\mathrm{N}$ exhibition are important to create awareness among citizens. This increases the chances that citizens will accept and make effective use of the new technology and the products when they finally reach the market.

For investors, the higher degree of public acceptance reduces the delay or resistance of investing in lowrevenue components of the smart grid. Public education, available at science centers and exhibitions, is a significant part for the German socio-technical transition, which supports consumers in learning to prepare for the smarter future. The Expedition $\mathrm{N}$ mobile exhibition moves to different areas, where it provides a free experience. It acts as a bridge between the unpredictable future and the current awkward and difficult implementation phase. Moreover, it provides citizens who do not have the opportunity to participate in the field tests of smart grid-related applications with hands-on experience of new technologies, no matter whether they are old or young, conservative or progressive, technology freaks or technology shy. 


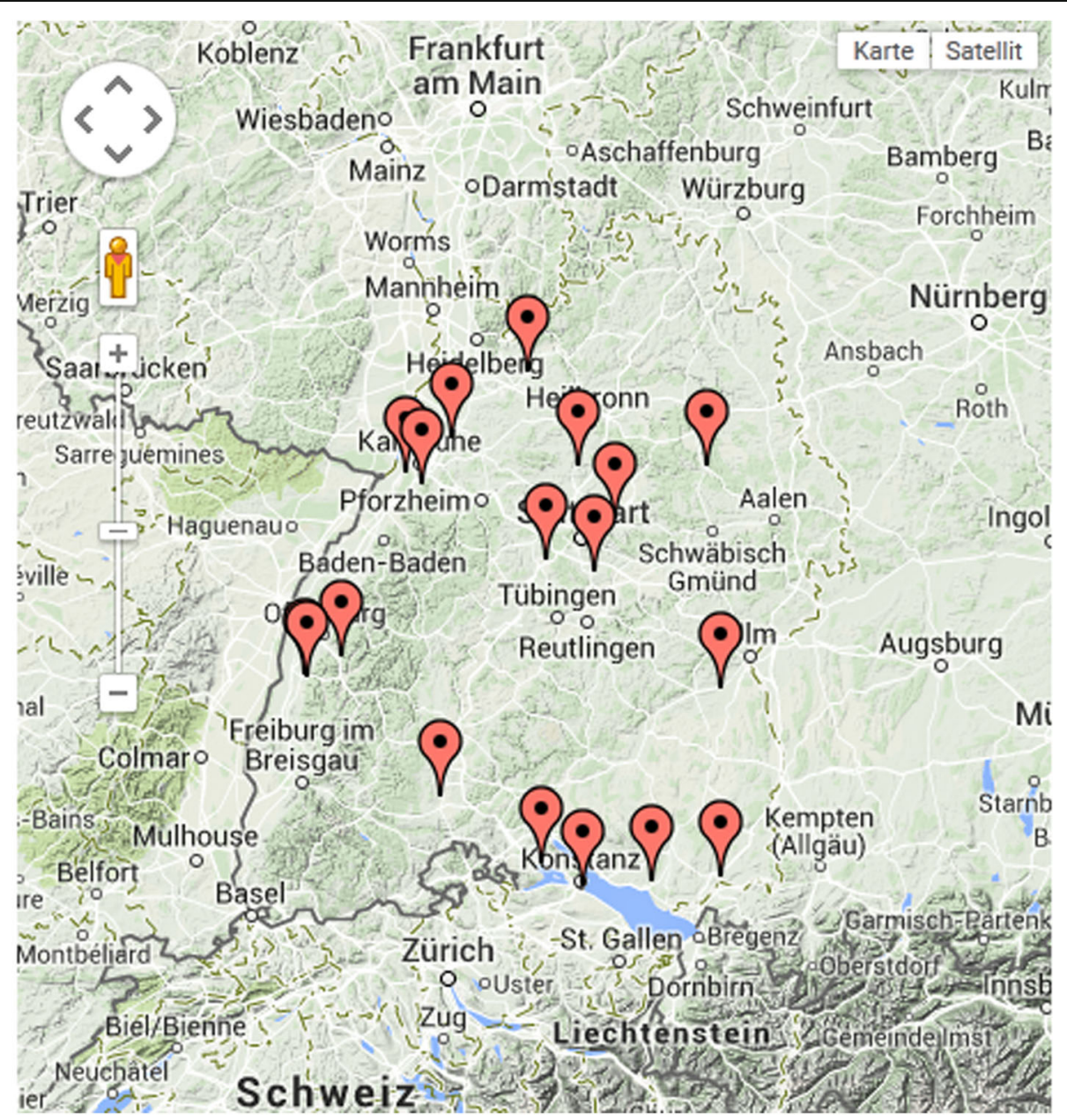

Fig. 9 The Expedition N vehicle travel plan in the Baden-Württemberg state of Germany (from mid-December of 2014 to March of 2015)

\section{Conclusions}

The German energy transition is heatedly discussed not only within Germany but also throughout the world. Even if energy technologies are feasible, consumer acceptance and public participation take time to evolve.

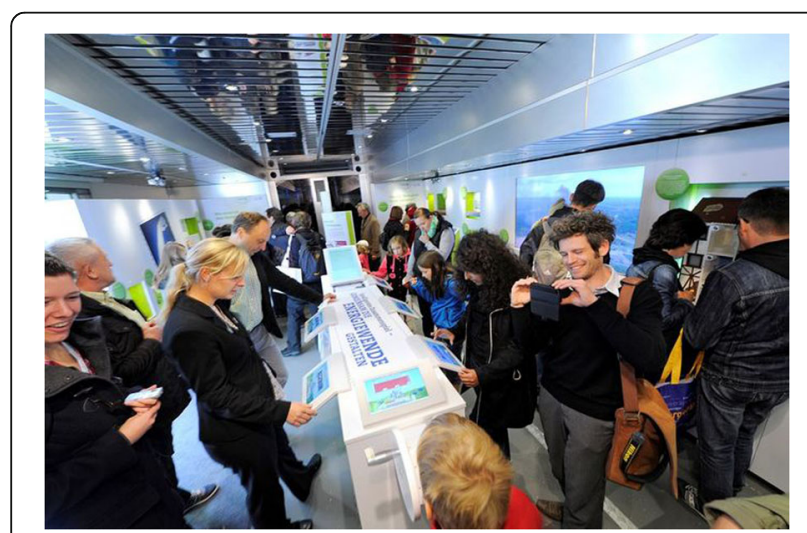

Fig. 10 Big event on the German National Day
And, effective participation needs citizens with basic knowledge of energy concepts and processes for reasoned arguments and actions. This article provides a perspective from public education on the integrations of citizens in the societal transition. The innovative mobile exhibition with the interactive simulation game provided by the Baden-Württemberg Stiftung, offering a systematic view of the whole energy system, is arousing citizens' interest in becoming aware of and learning about the smart grid and moving toward a smarter way of using energy.

The main lesson from the exhibition has been that given a well-balanced mix of basic information, opportunities for self-experimentation and reflection, quizzes and tests, as well as role playing for enabling visitors to exchange their impressions with others proved to be very attractive (more than $80 \%$ gave highly favorable reviews of the exhibition ${ }^{14}$ ) and also very productive with respect to knowledge acquisition and personal learning. 


\section{Endnotes}

${ }^{1}$ In German, it is called "Expeditionsziel Energiewende". Please click (http://www.expeditionn.de/) for more information.

${ }^{2}$ The grand opening took place in Stuttgart, on October 3, 2013, which is the "Tag der Deutschen Einheit" (German National Day).

${ }^{3}$ Source: Baden-Württemberg Stiftung. Pressebilder: Smart grid game platform ("Netz-Spiel" in German). Accessed March 6, 2015. Available at: http://www. expeditionn.de/news-presse/pressebilder/pressebilderexponate.html?tx_wtgallery_pi1[show] $=8975925 \& \mathrm{cHash}=$ ff72e0f066a17ed73a3d922e7454b49a.

${ }^{4}$ Source: Baden-Württemberg Stiftung. Pressebilder: Expeditionsmobil Außenansicht. Accessed March 6, 2015. Available at: http://www.expeditionn.de/news-presse/ pressebilder/pressebilder-aussenansicht.html?tx_wtgallery_ pi1 $[$ show $]=237351248 \&$ cHash=b410eaef55c6bbaae7de623 a4c4fae91.

${ }^{5}$ The Expedition $\mathrm{N}$ vehicle is operated by FLAD \& FLAD Communication $\mathrm{GmbH}$ on behalf of the BadenWürttemberg Stiftung.

${ }^{6}$ Source: Baden-Württemberg Stiftung. Energie-ForscherPraktikum. Accessed March 6, 2015. Available at: http:// www.expeditionn.de/news-presse/pressebilder/pressebilderpraktikum.html?tx_wtgallery_pi1[show]=95074119\&cHash= de75bf4b5435e859468b919a3288eafa.

${ }^{7}$ Source: Baden-Württemberg Stiftung. Pressebilder: Film presentation room. Accessed March 6, 2015. Available at: http://www.expeditionn.de/news-presse/pressebilder/presse bilder-buergerfest-tag-der-dt-einheit.html?tx_wtgallery_pi1 [show $]=225332599 \& \mathrm{cHash}=\mathrm{b} 6 \mathrm{~d} 8 \mathrm{a}$ e $957097200014 \mathrm{bf} 9 \mathrm{f6} 82$ afa186.

${ }^{8}$ Source: Baden-Württemberg Stiftung. Pressebilder: Exponate. Accessed March 6, 2015. Available at: http:// www.expeditionn.de/news-presse/pressebilder/pressebilderexponate.html?tx_wtgallery_pi1[show] $=119601142 \&$ cHash $=$ b552d118c33ecda30eeddd855fe41e4d.

${ }^{9}$ The smart grid game ("Netz-Spiel" in German) was realized and is operated by Takomat $\mathrm{GmbH}$.

${ }^{10}$ The data is obtained from Baden-Württemberg Stiftung.

${ }^{11}$ The data is obtained from Baden-Württemberg Stiftung.

${ }^{12}$ Source: Baden-Württemberg Stiftung. Stationen: Das Expeditionsmobil zu Besuch. Accessed March 6, 2015. Available at: http://www.expeditionn.de/tour/stationenneu/article/0.html?tx_ttnews[calendarYear] $=2015 \&$ tx_tt news [calendarMonth] $=2 \& \mathrm{cHash}=\mathrm{f} 71 \mathrm{~d} 69746 \mathrm{bb} 80 \mathrm{cac} 857$ 34a813e02d9d4.

${ }^{13}$ Source: Baden-Württemberg Stiftung. Pressebilder: Expedition N beim Bürgerfest zum Tag der Deutschen Einheit. Accessed March 6, 2015. Available at: http://www. expeditionn.de/news-presse/pressebilder/pressebilder-buer gerfest-tag-der-dt-einheit.html?tx_wtgallery_pi1\%5Bshow\%5 $\mathrm{D}=13258153 \& \mathrm{cHash}=\mathrm{e} 52 \mathrm{e} 28 \mathrm{~b} 0 \mathrm{a} 2786 \mathrm{e} 55 \mathrm{f} 3381 \mathrm{ab} 9 \mathrm{fbb} 8277 \mathrm{a}$.
${ }^{14}$ The data is obtained from Baden-Württemberg Stiftung.

\section{Competing interests}

The authors declare that they have no competing interests.

\section{Authors' contributions}

$\mathrm{HL}$ participated in the design and implementation of the smart grid game. $\mathrm{IC}$ and $\mathrm{OR}$ redesigned the mobile exhibition, including the game concept. $\mathrm{HL}$ drafted the first version of this paper. $\mathrm{HL}, \mathrm{IC}$, and $\mathrm{OR}$ finalized the manuscript. AW was in charge of the mobile exhibition project. He provided important introductory materials and has checked key facts and figures. GM polished the language of the initial draft and made significant comments to adjust the structure. All authors read and approved the final manuscript.

\section{Authors' information}

HL is a Ph.D. student at ZIRIUS (email: Huijie.Li@sowi.uni-stuttgart.de). IC is Senior Fellow at the Institute for Advanced Sustainability Studies in Potsdam, Germany, and Chair of the Knowledge, Learning, and Societal Change International Alliance (email: ilan.chabay@iass-potsdam.de). OR serves as a full professor and Chair of Environmental Sociology and Technology Assessment at the University of Stuttgart (email: ortwin.renn@sowi.uni-stuttgart.de). AW is the head of the Education Department of Baden-Württemberg Stiftung (email: weber@bwstiftung.de). GM is a junior researcher in the non-profit company DIALOGIK (email: mbungu@dialogik-expert.de).

\section{Author details}

${ }^{1}$ Stuttgart Research Center for Interdisciplinary Risk and Innovation Studies (ZIRIUS), University of Stuttgart, Seidenstr. 36, Stuttgart 70174, Germany. ${ }^{2}$ Institute for Advanced Sustainability Studies (IASS), Berliner Straße 130, Potsdam 14467, Germany. ${ }^{3}$ Department of Technology and Environmental Sociology, University of Stuttgart, Seidenstr. 36, Stuttgart 70174, Germany. ${ }^{4}$ DIALOGIK Non-profit Institute for Communication and Cooperation Research, Lerchenstr. 22, Stuttgart 70176, Germany. ${ }^{5}$ Baden-Württemberg Stiftung, Kriegsbergstr. 42, Stuttgart 70174, Germany.

Received: 27 June 2015 Accepted: 3 December 2015

Published online: 22 December 2015

\section{References}

1. EU Commission Task Force for Smart Grids, Expert Group 1 (2010) Functionalities of smart grids and smart meters. Final deliverable, Brussels

2. Henriksen EK, Frøyland M (2000) The contribution of museums to scientific literacy: views from audience and museum professionals. Public Understanding of Science J 9(4):393-415. doi:10.1088/0963-6625/9/4/304

3. Falk JH, Storksdieck M, Dierking LD (2007) Investigating public science interest and understanding: evidence for the importance of free-choice learning. Public Understanding of Science J 16(4):455-469. doi:10.1177/0963662506064240

4. Lach D, Sanford S (2010) Public understanding of science and technology embedded in complex institutional settings. Public Understanding of Science J 19(2):130-146. doi:10.1177/0963662508096783

5. Baden-Württemberg Stiftung (2010) Expeditionsziel: Nachhaltigkeit. Stuttgart. Accessed 24 June 2015. Available at: http://www.bwstiftung.de/ uploads/tx_news/SR-48_ExpeditionN-Nachhaltigkeit.pdf

6. Crowell A, Schunn C (2014) Scientifically literate action: key barriers and facilitators across context and content. Public Understanding of Science J 23(6):718-733. doi:10.1177/0963662512469780

7. Kamolpattana S, Chen G, Sonchaeng P, Wilkinson C, Willey N, Bultitude K (2015) Thai visitors' expectations and experiences of explainer interaction within a science museum context. Public Understanding of Science J 24(1):69-85. doi:10.1177/0963662514525560

8. National Research Council (2009) Learning science in informal environments: people, places, and pursuits. Committee on Learning Science in Informal Environments. In: Bell P, Lewenstein B, Shouse AW, Feder MA (eds) Board on Science Education, Center for Education, Division of Behavioral and Social Sciences and Education. The National Academies Press, Washington, DC

9. Heath C (2008) Configuring 'interactivity': enhancing engagement in science centres and museums. Social Studies of Science 38:63-91. doi:10.1177/ 0306312707084152

10. Perspektive (2013) Expeditionsmobil neu entdeckt. Perspektive 2:46-49, Accessed 11 October 2015. Available at:http://www.iass-potsdam.de/sites/default/files/ files/article_in_perspektive_on_energiewende_exhibion_mobile_2.pdf 